\title{
Application of Bambara Groundnut in the Production of Cookies
}

\author{
Omolara R. Adegbanke* Duyilemi O. Ojo-uyi Timilehin D. Oluwajuyitan \\ Department of Food Science and Technology, Federal University of Technology, \\ Akure, P.M.B. 704, Akure, Nigeria
}

\begin{abstract}
This study aimed to produce cookies from flour blends of Bambara groundnut (BGN) and wheat flour (WF) at ratios 100:0, 80:20, 70:30, 60:40, 50:50 and 0:100 (WF: BGN) respectively. The proximate results showed significant differences $(p \geq 0.05)$ among the flour blends with protein, crude fibre, crude fat, total ash and carbohydrate content ranged from $9.30-22.75 ; 0.42-2.42 ; 12.51-18.98 ; 0.91-2.99$ and $43.62-71.38 \%$ respectively. The increase in the protein and fat content resulted from the increase in BGN of the blend flour respectively. The functional properties of the blend flours showed that oil absorption capacity (OAC), water absorption capacity (WAC), swelling index and bulk density ranged from $3.08-4.20 ; 2.00-2.30 ; 1.05-1.31$ and $0.62-0.72 \mathrm{~g} / \mathrm{ml}$ respectively. However the low OAC and WAC of BGN blend flour might be due to low levels of hydrophobicity of proteins. All cookies had a good sensory scores, except cookies made from $100 \%$ BGN, therefore up to $50 \%$ BGN flour be used in the substitution of WF in the production of cookies for adequate nutritional quality.
\end{abstract}

Keywords: Bambara groundnut, cookies, functional, physical, sensory evaluation.

DOI: $10.7176 / \mathrm{FSQM} / 83-07$

\section{Introduction}

Most cookies are low in protein and if present is often of poor nutritional quality. This is because they are prepared mostly from plants food products, especially cereals Akpapunam and Darbe (1994). The world protein demand is on the increase Eltayeb et al. (2011) and so the need for improvement of cookies as they are highly consumed by both children and adult. If properly processed and enriched, using local available protein source, it may help as a channel to manage the world protein deficiency, must especially of the low income group, who cannot afford expensive western food.

Bambara groundnut (Vigna subterranean) is a legume extensively cultivated in Nigeria and many African

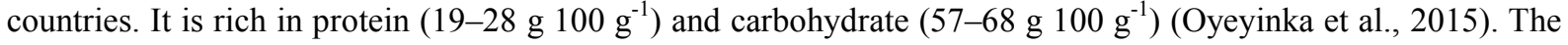
proteins of BGN may be used as a functional ingredient in the industry due to its balanced amino acid profile (Bamshaiye et al., 2011).

Wheat (Triticum aestivum L) is the most extensively grown cereal crop in the world, Wheat has been cultivated in Nigeria for centuries (Olugbemi et al., 1979; Ohiagu et al., 1987). However, Oyewole (2016) reported that Nigeria's domestic wheat production has remained at a very low level in spite of the ever rising demand for the crop due to climatic requirements, appropriate agronomic practices and preference for the cultivation of vegetables (Ohiagu et al., 1987). In the present study, cookies made from the blends of BGN and WFwere analysed for their proximate composition, functional properties, physical properties, and sensory evaluation in order to establish the best blend for cookies production and enrichment.

\section{Materials and methods}

2.1 Materials

Bamabara groundnut (Vigna subterranea) and Whole wheat (Triticum eastrum) flour used for this study were purchased from Oja Oba market, Akure, and authenticated at the Department of Crop, Soil and Pest Management, Federal University of Technology, Akure. All chemicals are analytical grade and were purchased from Sigma Chemicals (St. Louis, MO, USA).

\subsection{Methods}

Sample preparations

Bambara groundnut (BGN) was processed into flour using a modified method described by Nwosu. (2013). BGN were sorted, soaked with distilled water at ratio $1: 2$ for $24 \mathrm{~h}$ at room temperature, dehulled using attrition mill, dried using electrical air-oven at $60{ }^{\circ} \mathrm{C}$ for $3 \mathrm{~h}$, milled into a fine particle size using electrical stainless steel blender, sieved using $1 \mathrm{~mm}$ sieve. The fine flour of the groundnut was blend with whole WF using the blending ratios (100:0, 90:10, 80:20, 70:30, 60:40, 50:50 and 100:0\%) of BGN flour and whole WF labelled WB1, WB2, WB3, WB4, WB5 and WB6, respectively.

Preparation of cookies

The cookies was prepared by the procedure described by Okaka (2009) using the recipe shown in Table 1 . The fat and sugar were mixed until fluffy. Egg and milk were added while mixing continued for 40 min, appropriate 
amount of flour, baking powder, nut-meg, vanilla flavouring and salt were slowly introduced into the mixture. The dough was rolled and cut into circular shapes of $5 \mathrm{com}$ diameter. Baking was carried out at $120{ }^{\circ} \mathrm{C}$ for 25 min using the flour blends. The cookies was collected and stored in a closed high density polyethene nylon until further analysis.

Table I: Recipe for cookies production

\begin{tabular}{lc}
\hline Ingredients & Quantity $(\mathrm{g})$ \\
\hline Flour & 500.00 \\
Fat (Vegetable oil) & 200.00 \\
Sugar & 125.00 \\
Salt & 5.00 \\
Egg & 2.50 \\
Milk & 7.50 \\
Nut-meg & 1.50 \\
Vanilla flavour & 2.50 \\
Baking powder & 5.00 \\
\hline
\end{tabular}

2.3 Determination of functional properties of bamabara groundnut-wheat flour blends

Oil \& Water Absorption Capacity $(O A C \& W A C)$

Oil and water absorption capacity of flours blends determined according to the centrifugation method (AOAC 2005).

Swelling index (SI)

The method of Ukpabi and Ndimele (1990) was used. Fifty grams of each flour samples were put into a $500 \mathrm{~mL}$ measuring cylinders. Three hundred (300) $\mathrm{mL}$ of cold water were added and allowed to stand for $4 \mathrm{~h}$ before observing the level of swelling. The swelling index were then calculated as the multiple of the original volume.

Bulk density $(B D)$

Bulk density was estimated as described by Maninder et al. (2007). The flour samples were gently filled into 10 $\mathrm{ml}$ graduated cylinders, previously tared. The bottom of each cylinder was gently tapped on a laboratory bench several times until there was no further diminution of the sample level after filling to the $10 \mathrm{ml}$ mark. Bulk density was calculated as weight of sample per unit volume of sample $\left(\mathrm{g} \mathrm{ml}^{-1}\right)$. Measurements were made in triplicate.

2.4 Determination of physical properties of bamabara groundut-wheat flour cookies

Weight

The weight of cookies was determined using Oluwamukomi et al. (2011). The weight of the biscuits was measured by weighing on a weighing balance (Model Mettler PE1600, Mettler Instruments Corporation, Greifensee, Zurich, Switzerland) with an accuracy of $0.1 \mathrm{mg}$ ).

Diameter

Diameter was estimated using Ayo et al. (2007) method. The diameter was measured with a calibrated ruler.

Spread ratio and Height

The spread ratio was determined using Ayo et al. (2007) method. Three rows of the five well-formed biscuits were made and the height measured as well as arranging the same biscuits horizontally edge and the sum of the diameter measured.

$$
\text { Spread ratio }=\frac{\text { Diameter }}{\text { Height }}
$$

2.5 Determination of proximate composition of Bambara groundnut-wheat flour cookies

Proximate composition was determined using the method of A.O.A.C. (2005) and the carbohydrate content was obtained by difference.

2.6 Sensory evaluation of Bambara groundnut-wheat flour cookies

Sensory analysis was carried out on the cookies produced from each of the flour blends. Thirty (30) members' semi-trained panelists were involved. Quality attributes evaluated were appearance, texture, taste, flavor, crispiness, and overall acceptability using a 9-point Hedonic scale, where 9 is like extremely and 1 is dislike extremely.

\subsection{Statistical analysis}

Triplicate replications were used to obtain mean values and standard deviations. Statistical analysis was performed with SAS (Statistical Analysis Software 17.0, USA) using one-way ANOVA. Duncan's multiplerange test was carried out to compare the mean values for samples with significant differences taken at $p<0.05$. 


\subsection{Results and discussion}

3.1 Proximate Composition

The result of the proximate composition of the flour blends is presented in Table 2. The result shows that the moisture content of the flour ranges from 3.40-11.24\%, crude protein, 9.38-22.75\%; crude fibre, $0.42-2.42 \%$; crude fat, 12.51-18.98\%; total ash, $0.91-2.99 \%$ and carbohydrate, $43.62-71.38 \%$. The protein content $(22 \%)$ of BGN flours (WB6) obtained in this present finding is significantly $(p \leq 0.05)$ higher than the $9 \%$ of whole WF (WB1). The protein content of the flour sample increase with increasing BGN flour. This was expected since BGN is a legume while wheat is a cereal grain and legumes naturally contain more protein than cereals although the prevalent protein in wheat occurs as gluten which is needed in baking. The protein content of WB6 is in agreement with values (21-28 g $100 \mathrm{~g}^{-1}$ ) reported from past studies (Adebowale et al., 2002; Arise et al., 2015; Oyeyinka et al., 2018). Moisture, ash and crude fibre of the flour blends were generally low and are similar to the findings of Oyeyinka et al., 2018. In contrast, the present crude fiber contents obtained in this study $(0.42 \%)$ is lower than the $1.47 \%$ reported by Oyeyinka et al., 2018 and this could be influence by difference source, origin and processing conditions respectively.

Table II: Proximate composition (\%) of Bamabara groundnut-wheat flour blend

\begin{tabular}{lcccccc}
\hline Samples & Moisture & Protein & Crude Fibre & Crude Fat & Total Ash & Carbohydrate \\
\hline WB1 & $3.40 \pm 0.10^{\mathrm{d}}$ & $9.38 \pm 0.12^{\mathrm{f}}$ & $2.42 \pm 0.01^{\mathrm{a}}$ & $12.51 \pm 0.07^{\mathrm{e}}$ & $0.91 \pm 0.01^{\mathrm{d}}$ & $71.38 \pm 0.11^{\mathrm{a}}$ \\
WB2 & $5.72 \pm 0.70^{\mathrm{c}}$ & $11.68 \pm 0.08^{\mathrm{e}}$ & $2.16 \pm 0.04^{\mathrm{b}}$ & $18.08 \pm 0.03^{\mathrm{d}}$ & $1.35 \pm 0.58^{\mathrm{c}}$ & $61.01 \pm 0.03^{\mathrm{c}}$ \\
WB3 & $5.89 \pm 0.12^{\mathrm{b}}$ & $11.83 \pm 0.05^{\mathrm{d}}$ & $1.97 \pm 0.02^{\mathrm{c}}$ & $18.16 \pm 0.02^{\mathrm{c}}$ & $1.22 \pm 0.02^{\mathrm{c}}$ & $60.93 \pm 0.44^{\mathrm{bc}}$ \\
WB4 & $5.06 \pm 0.40^{\mathrm{c}}$ & $12.56 \pm 0.06^{\mathrm{c}}$ & $1.87 \pm 0.03^{\mathrm{d}}$ & $18.22 \pm 0.24^{\mathrm{bc}}$ & $1.10 \pm 0.02^{\mathrm{c}}$ & $61.19 \pm 0.10^{\mathrm{b}}$ \\
WB5 & $5.59 \pm 0.02^{\mathrm{c}}$ & $14.58 \pm 0.06^{\mathrm{b}}$ & $1.87 \pm 0.01^{\mathrm{d}}$ & $18.54 \pm 0.02^{\mathrm{b}}$ & $2.65 \pm 0.01^{\mathrm{b}}$ & $56.77 \pm 0.06^{\mathrm{c}}$ \\
WB6 & $11.24 \pm 0.23^{\mathrm{a}}$ & $22.75 \pm 0.02^{\mathrm{a}}$ & $0.42 \pm 0.02^{\mathrm{e}}$ & $18.98 \pm 0.04^{\mathrm{a}}$ & $2.99 \pm 0.02^{\mathrm{a}}$ & $43.62 \pm 0.26^{\mathrm{d}}$ \\
\hline
\end{tabular}

Values are Means \pm SEM. Values with different superscripts within the same column are significantly different $(p \leq 0.05)$.

Keys: WB1 $=100 \%$ Wheat flour, WB2 $=80 \%$ Wheat flour and 20\% Bambara flour, WB3 $=70 \%$ Wheat flour and 30\% Bambara flour, WB4 $=60 \%$ Wheat flour and $40 \%$ Bambara flour, WB5 $=50 \%$ Wheat flour and $50 \%$ Bambara flour, WB6 = 100\% Bambara flour.

\subsection{Functional properties}

The functional properties of samples is shown in Table 3. The values ranges from $3.08-4.20 ; 2.00-2.30 ; 1.05-$ 1.31 and $0.62-0.72 \mathrm{~g} / \mathrm{ml}$ for Oil Absorption Capacity (OAC), Water absorption Capacity (WAC), Swelling Index (SI) and Bulk Density (BD) respectively. There was a significant difference ( $p \geq 0.05)$ between 100\% WF sample (WB1) and other samples substituted with BGN as WB1 exhibited the highest OAC \& WAC (4.20 g oil $\mathrm{g}^{-1}$ sample and $2.40 \mathrm{~g}_{\text {water }} \mathrm{g}^{-1}$ sample) while the $100 \%$ BGN flour (WB6) had the lowest OAC \& WAC (3.08 g oil g $\mathrm{g}^{-1}$ sample and $2.00 \mathrm{~g}$ water $\mathrm{g}^{-1}$ sample). The findings in this report is close to $3.65 \mathrm{~g} \mathrm{oil} \mathrm{g}^{-1}$ findings of Akpapunam and Darbe (1993) but slightly lower than $3.80 \mathrm{~g}$ water $\mathrm{g}^{-1}$ of BGN flour. Although the finding in this report are in agreement with Abbeh and Ibeh (1987) findings. The low OAC and WAC of BGN products flour might be due to low levels of hydrophobicity of proteins which show superior binding of lipids. The bridge caused by protein in fat and water emulsion may not make BGN flour products a suitable ingredient in the cold meat industry particularly for sausages.

The swelling index increase (1.05-1.31) significantly $(p \leq 0.05)$ as the BGN flour increases within the samples from $0 \%$ up to $100 \%$, while no significant difference $(p \leq 0.05)$ was observed in bulk density $\left(0.62 \mathrm{~g} \mathrm{ml}^{-1}\right)$ of substituted blend samples of BGN flour from $20 \%-100 \%$. This result were comparable to 0.56 and $0.62 \mathrm{~g} \mathrm{ml}^{-1}$ reported by previous findings (Eltayeb et al., 2011 and Adeleke et al., 2018). The presence of higher proportion of carbohydrate in WF may be responsible for the high BD demonstrated. Starch polymer structure has been seen to influence BD and loose starch polymer could result in low bulk density (Plaanmi 1997).

Table III: Functional properties $\left(\mathrm{g} \mathrm{ml}^{-1}\right)$ of Bambara groundnut-wheat flour blend

\begin{tabular}{ccccc}
\hline Samples & Oil absorption & Water absorption & Swelling index & Bulk density \\
\hline WB1 & $4.20 \pm 0.20^{\mathrm{a}}$ & $2.30 \pm 0.30^{\mathrm{a}}$ & $1.05 \pm 0.02^{\mathrm{c}}$ & $0.72 \pm 0.10^{\mathrm{a}}$ \\
WB2 & $3.40 \pm 0.20^{\mathrm{b}}$ & $2.00 \pm 0.02^{\mathrm{b}}$ & $1.06 \pm 0.03^{\mathrm{c}}$ & $0.69 \pm 0.03^{\mathrm{ab}}$ \\
WB3 & $3.40 \pm 0.01^{\mathrm{b}}$ & $2.00 \pm 0.01^{\mathrm{b}}$ & $1.06 \pm 0.03^{\mathrm{c}}$ & $0.69 \pm 0.01^{\mathrm{ab}}$ \\
WB4 & $3.20 \pm 0.02^{\mathrm{b}}$ & $2.00 \pm 0.02^{\mathrm{b}}$ & $1.11 \pm 0.01^{\mathrm{b}}$ & $0.66 \pm 0.03^{\mathrm{ab}}$ \\
WB5 & $3.20 \pm 0.02^{\mathrm{b}}$ & $2.00 \pm 0.01^{\mathrm{b}}$ & $1.12 \pm 0.02^{\mathrm{b}}$ & $0.64 \pm 0.02^{\mathrm{ab}}$ \\
WB6 & $3.08 \pm 0.20^{\mathrm{c}}$ & $2.00 \pm 0.03^{\mathrm{b}}$ & $1.31 \pm 0.01^{\mathrm{a}}$ & $0.62 \pm 0.03^{\mathrm{ab}}$
\end{tabular}

Values are Means \pm SEM. Values with different superscripts within the same column are significantly different $(p \leq 0.05)$.

Keys: WB1 $=100 \%$ Wheat flour, WB2 $=80 \%$ Wheat flour and 20\% Bambara flour, WB3 $=70 \%$ Wheat flour and 30\% Bambara flour, WB4 $=60 \%$ Wheat flour and $40 \%$ Bambara flour, WB5 $=50 \%$ Wheat flour and $50 \%$ Bambara flour, WB6 $=100 \%$ Bambara flour. 


\subsection{Physical characteristics}

Physical parameter of Bambara groundnut-wheat cookies are presented in Table 4. Values ranges from 10.06$12.01 \mathrm{~g}, 0.57-1.08 \mathrm{~cm}, 5.07-6.31 \mathrm{~cm}$ and $9.76-10.96$ for weight, height, diameter and spread ratio respectively. Weight of the cookies increase significantly $(p \geq 0.05)$ with increase in the amount of BGN in the sample blends and this effect is applicable to height, diameter and spread ratio. Cookies made from $100 \%$ WF cookies (WB1) had the least weight (10.06 g), while 100\% BGN flour cookies had (12.01 g) weight and this is similar to $13.78 \mathrm{~g}$ of cookies made from BGN flour as reported by Akpapunam and Darbe (1993). There is no significant difference $(p \geq 0.05)$ in the spread ratio of the cookies made from WF and those made from blend constituted with BGN flour however, significantly $(p \geq 0.05)$ lower than cookies make form $100 \%$ BGN flour. Table IV: Physical characteristics of Bambara groundnut-wheat flour cookies

\begin{tabular}{ccccc}
\hline Samples & Weight $(\mathrm{g})$ & Height $(\mathrm{cm})$ & Diameter $(\mathrm{cm})$ & Spread ratio \\
\hline WB1 & $10.06 \pm 0.18^{\mathrm{b}}$ & $0.67 \pm 0.06^{\mathrm{bc}}$ & $5.07 \pm 0.35^{\mathrm{c}}$ & $9.76 \pm 0.10^{\mathrm{b}}$ \\
WB2 & $10.20 \pm 0.62^{\mathrm{b}}$ & $0.50 \pm 0.10^{\mathrm{bc}}$ & $5.12 \pm 0.03^{\mathrm{c}}$ & $10.04 \pm 2.10^{\mathrm{ab}}$ \\
WB3 & $10.32 \pm 0.01^{\mathrm{b}}$ & $0.57 \pm 0.06^{\mathrm{bc}}$ & $5.47 \pm 0.12^{\mathrm{c}}$ & $10.13 \pm 0.96^{\mathrm{ab}}$ \\
WB4 & $10.66 \pm 0.77^{\mathrm{b}}$ & $0.57 \pm 0.12^{\mathrm{bc}}$ & $5.60 \pm 0.10^{\mathrm{b}}$ & $10.35 \pm 1.99^{\mathrm{ab}}$ \\
WB5 & $11.26 \pm 0.73^{\mathrm{b}}$ & $0.70 \pm 0.01^{\mathrm{b}}$ & $5.77 \pm 0.21^{\mathrm{b}}$ & $10.58 \pm 1.51^{\mathrm{ab}}$ \\
WB6 & $12.01 \pm 0.01^{\mathrm{a}}$ & $1.08 \pm 0.03^{\mathrm{a}}$ & $6.31 \pm 0.01^{\mathrm{a}}$ & $10.96 \pm 0.03^{\mathrm{a}}$ \\
\hline
\end{tabular}

Values are Means \pm SEM. Values with different superscripts within the same column are significantly different $(p \geq 0.05)$.

Keys: WB1 $=100 \%$ Wheat flour, WB2 $=80 \%$ Wheat flour and 20\% Bambara flour, WB3 $=70 \%$ Wheat flour and $30 \%$ Bambara flour, WB4 $=60 \%$ Wheat flour and $40 \%$ Bambara flour, WB5 $=50 \%$ Wheat flour and $50 \%$ Bambara flour, WB6 $=100 \%$ Bambara flour.

\subsection{Sensory evaluation}

The result of sensory evaluation is shown in Table 5 below. From the results; it was observed that the best crispness as indicated by the panellist was from the 100\% WF (WB1) cookies which had a mean value of 6.80 closely followed by the product from $10 \%$ and $20 \%$ substitutions with BGN which had 6.70 and 6.60 respectively, though there was no significant difference $(p \geq 0.05)$ between them. There occurred a significant difference $(p \leq 0.05)$ with $100 \%$ BGN (WB6). From the result, the crispness of the biscuits decreased with increase in the level of BGN flour. This could be attributed to the lower gluten content of BGN since gluten is responsible for the extensibility of the dough.

Based on appearance, the WB1 sample ranked highest with a mean value of 7.70 . This was very close to $20 \%$ substitutions of 7.35 and there was no significant difference $(p \geq 0.05)$ between the two samples. Substitution up to $30: 70 ; 40: 60$ and even up to 50:50 (Bambara: wheat) were fairly accepted by the panelists having a score of 6.30 ; and up to (100\% Bambara) with a mean value of 4.96 .

Based on Aroma, there was a significant difference $(p \geq 0.05)$ between WB1 and other samples. But there was no significant difference ( $p \geq 0.05$ ) among substituted samples up to 50:50 substitutions (Bambara: wheat). Although there was a significant difference $(p \geq 0.05)$ between WB2-5 (6.95) and WB6 (4.96). Since aroma is a determining factor in consumers' acceptance of cookies it can be deduced that the biscuit is accepted up to $50 \%$ substitution with BGN. The only handicap is the slight aroma of the beamy off flavour that was still noticed.

From the results of the overall acceptability of the samples, there was no significant difference $(p \geq 0.05)$ between samples WB1, WB2, WB3 (up to 40\% substitution with BGN) with mean scores of 7.40, 7.30 and 6.95 respectively. Also up to $50 \%$ substitution with a mean score of 6.35 was slightly liked by panelists. This showed that the panelists accepted this product up to $50 \%$ level of substitution of WF with BGN flour. Since all the parameters used in this sensory evaluation had good sensory scores, it could be recommended that up to $50 \%$ BGN flour be used in the substitution of WF in the production of cookies.

Table V: Sensory evaluation of Bambara groundnut-wheat flour cookies

\begin{tabular}{cccccc}
\hline Samples & Taste & Aroma & Crispness & Appearance & Overall acceptability \\
\hline WB1 & $7.70 \pm 0.92^{\mathrm{a}}$ & $7.10 \pm 1.20^{\mathrm{a}}$ & $6.80 \pm 1.72^{\mathrm{a}}$ & $7.70 \pm 1.66^{\mathrm{a}}$ & $7.40 \pm 0.94^{\mathrm{a}}$ \\
WB2 & $6.70 \pm 1.41^{\mathrm{b}}$ & $5.60 \pm 1.50^{\mathrm{b}}$ & $6.70 \pm 1.65^{\mathrm{a}}$ & $7.35 \pm 1.33^{\mathrm{a}}$ & $7.30 \pm 1.30^{\mathrm{a}}$ \\
WB3 & $6.45 \pm 1.66^{\mathrm{b}}$ & $5.90 \pm 1.58^{\mathrm{b}}$ & $6.60 \pm 1.14^{\mathrm{a}}$ & $6.65 \pm 1.01^{\mathrm{b}}$ & $6.95 \pm 1.05^{\mathrm{ab}}$ \\
WB4 & $6.45 \pm 1.50^{\mathrm{b}}$ & $5.90 \pm 1.48^{\mathrm{b}}$ & $6.65 \pm 1.30^{\mathrm{a}}$ & $6.50 \pm 0.82^{\mathrm{b}}$ & $6.95 \pm 1.19^{\mathrm{ab}}$ \\
WB5 & $5.60 \pm 1.63^{\mathrm{b}}$ & $5.55 \pm 1.27^{\mathrm{b}}$ & $6.50 \pm 1.50^{\mathrm{a}}$ & $6.30 \pm 1.50^{\mathrm{b}}$ & $6.35 \pm 1.26^{\mathrm{b}}$ \\
WB6 & $4.01 \pm 0.05^{\mathrm{c}}$ & $4.31 \pm 0.11^{\mathrm{c}}$ & $5.16 \pm 0.14^{\mathrm{b}}$ & $4.06 \pm 0.16^{\mathrm{c}}$ & $4.96 \pm 0.04^{\mathrm{c}}$
\end{tabular}

Values are Means \pm SEM. Values with different superscripts within the same column are significantly different $(p \leq 0.05)$.

Keys: WB1 $=100 \%$ Wheat flour, WB2 $=80 \%$ Wheat flour and 20\% Bambara flour, WB3 $=70 \%$ Wheat flour and 30\% Bambara flour, WB4 $=60 \%$ Wheat flour and $40 \%$ Bambara flour, WB5 $=50 \%$ Wheat flour and $50 \%$ Bambara flour, WB6 $=100 \%$ Bambara flour. 


\section{Conclusion}

Wheat and Bambara flour can be combined to produce cookies with appreciable improved protein content, which can may be use in the management of protein energy malnutrition. The use of this flour blends will reduce the pressure on WF and help to improve the utilization of Bambara groundnut flour, and prevent it from going into extinction. This is an advantage in a non-traditionally wheat producing country like Nigeria. It is also of interest in child feeding programs and food for the low income groups.

\section{References}

Abbeh B.W. \& Ibeh, G.O. (1987). Functional properties of raw and heat processed brown bean (Canavalis rosea (SW)) flour. Journal of Food Science 52, p. $406-408$.

Adebowale, K.O., Afolabi, A.T. \& Lawal, S.O. (2002). Isolation, chemical and physicochemical characterization of Bambara groundnut (Voandzeia subterranean) starch and flour. Food Chemistry 78, p. 305-311.

Adeleke, R.O., Adiamo, Q.O. \& Fawale, S.O. (2018). Nutritional, Physicochemical, and functional properties of protein concentrate and isolate of newly developed Bambara groundnut (Vigna subterrenea L.) cultivars. Food Science and Nutrition 6, p. 229-242

Akpapunam, M.A. \& Darbe, J.W. (1994). Chemical composition and functional properties of blends of maize and Bambara groundnut flours for cookies production. Plant Foods for Human Nutrition 46, p. 147-155.

Arise, K.A., Amonsou, O.E. \& Ijabadeniyi A.O. (2015). Influence of extraction methods on the functional properties of protein concentrates prepared from South African Bambara groundnut landraces. International Journal of Food Science and Technology 50, p. 1095-1101.

Association of Official Analytical Chemist (A.O.A.C). (2005). Official Methods of Analytical Chemists, Arlington. $18^{\text {th }}$ Edition.

Ayo, J.A., Ayo, V.A., Nkama, I. \& Adewori, R. (2007). Physical, In-vitro Digestibility and Organoleptic Evaluation of "Acha" Wheat Biscuit supplemented with soybean flour. Nigeria Food Journal 25, p. 77-89.

Bamishaiye, O.M., Adegbola, J.A. \& Bamishaiye, E.I. (2011). Bambara groundnut: An under-utilized nut in Africa. Advances Agricultural Biotechnology 1, p. 42-51.

Belitz, H.D., Eltayeb, R.A., Ali, O.A., Abou-Arab, A. \& Abu-Salem, M.F. (2011). Chemical composition and functional properties of flour protein isolate extracted from Bambara groundnut (Vigna subterranean). African Journal of Food Science 5, p. 82-90.

Plaanmi, S.P. (1997). Content of dietary fiber in foods and its physiological effects. Food Reviews International 13 , p. $27-76$.

Maninder, K., Kawaljit, S. S. \& Narpinder, S. (2007). Comparative study of functional, thermal and pasting properties of flours from different field pea and pigeon pea cultivars. Food Chemistry, 104, p. 259-267.

Nwosu, J.N. (2013). Production and evaluation of biscuits from blends of bamabara groundnut (Vigna subterrancae) and wheat (Triticum eastrum) flour. International Journal of Food and Nutrition 2, $32 \mathrm{p}$.

Ohiagu, C.E., Ahmed, A. Orakwe, F.C., Maurya, P., Ajayi, O., Falaki, A. \& Kaul, N. (1987). A National Wheat Production Strategy: 1987-1996. Prepared by Cereal Research Programme, IAR, Amadu Bello University, Zaria., $67 \mathrm{p}$.

Okaka, J.C. (2009). Handling, storage and processing of plant foods. Academy Publishers. Enugu Nigeria.

Olugbemi, L.B., Redden, R., Aguda, E.V., Palmer, J. L., Balasubramania, V., Singh, L., Palmer-Jones, R. \& Dunham, R. (1979). History and status of wheat research in Nigeria. Samaru Miscellaneous Paper 85, 15 p.

Oluwamukomi, M.O., Oluwalana, I.B. \& Akinbowale. (2011). Physicochemical and sensory properties of wheatcassava composite biscuit enriched with soyflour. African Journal of Food Science 5, p. 50-56.

Oyewole, C. (2016). The wheat crop. Technical report, Department of Crop production, Faculty of Agriculture, Kogi state University, p. 1-16.

Oyeyinka, S.A. \& Oyeyinka A.T. (2018). A review on isolation, composition, physicochemical properties and modification of Bambara groundnut starch. Food Hydrocolloids 75, p. 62-71.

Oyeyinka, S.A., Singh, S., Adebola, P.O., Gerrano, A.S. \& Amonsou, E.O. (2015). Physicochemical properties of starches with variable amylose contents extracted from Bambara groundnut genotypes. Carbohydrate Polymers 133, p. 171-178.

Ukpabi, U.J. \& Ndimele, C. (1990). Evaluation of garri production in Imo state, Nigeria. Nigeria Food Journal 8 , p. $105-110$ 